U. S. Department of the Interior

U. S. Geological Survey

\title{
Potential Volcanic Hazards from Future Activity of Mount Baker, Washington
}

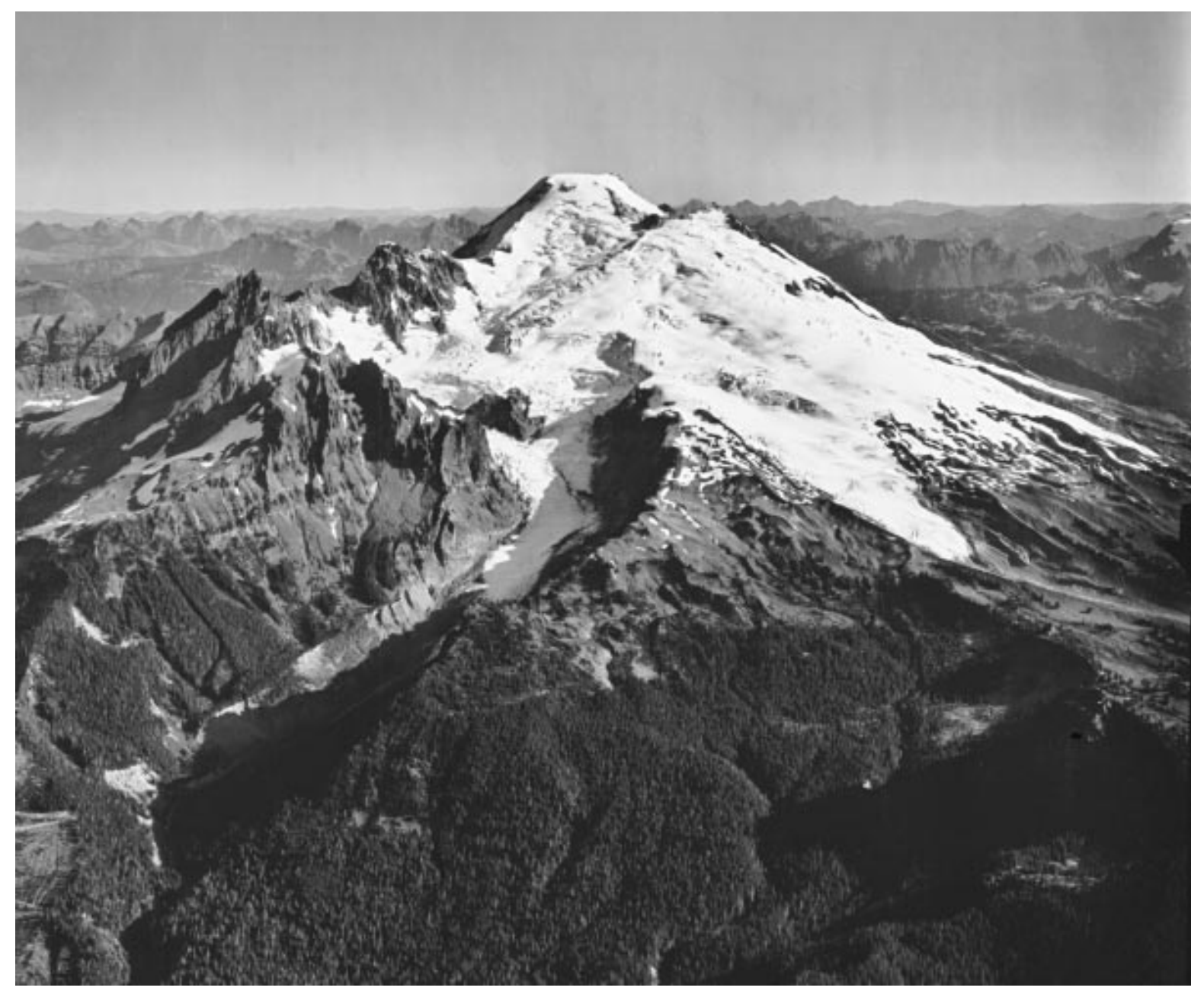

by

Cynthia A. Gardner ${ }^{1}$, Kevin M. Scott ${ }^{1}$, C. Dan Miller ${ }^{1}$, Bobbie Myers, ${ }^{1}$

Wes Hildreth $^{2}$, and Patrick T. Pringle ${ }^{3}$

1. U.S. Geological Survey, David A. Johnston Cascades Volcano Observatory, 5400 MacArthur Blvd., Vancouver, WA 98661

2. U.S. Geological Survey, MS 910, 345 Middlefield Rd., Menlo Park, CA 94025

3. Department of Natural Resources, Division of Geology and Earth Resources, PO Box 47007, Olympia, WA 98504-7007

\section{Open-File Report 95-498}

This report is preliminary and has not been reviewed for conformity with U.S. Geological Survey editorial standards or with the North American Stratigraphic Code. Any use of trade, firm, or product names is for descriptive purposes only and does not imply endorsement by the U.S. Government. 


\section{CONTENTS}

Introduction . . . . . . . . . . . . . . . . . . . . . . . . . . . . . . . . 1

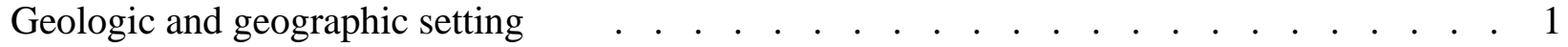

Volcanic phenomena - products and their associated hazards . . . . . . . . . . . . 2

Phenomena that can occur with or without an eruption $\quad$. . . . . . . . . . . . . 2

Debris flows . . . . . . . . . . . . . . . . . . . . . . . . . . 2

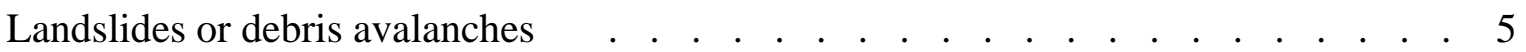

Volcanic phenomena that accompany eruptions . . . . . . . . . . . . . . . . . 5

Tephra . . . . . . . . . . . . . . . . . . . . . . . . . . 5

Ballistic debris . . . . . . . . . . . . . . . . . . . . . . . . . . . . . 8

Lava flows . . . . . . . . . . . . . . . . . . . . . . . . . . . . . . 8

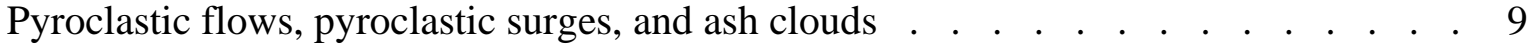

Lateral blasts . . . . . . . . . . . . . . . . . . . . . . . . . . . . . 9

Hazard-zonation map . . . . . . . . . . . . . . . . . . . . . . . . . . . . . 10

Debris-flow and debris-avalanche zone . . . . . . . . . . . . . . . . . . . . 10

Pyroclastic flow, surge, lava flow, and ballistic zone . . . . . . . . . . . . . . . . 11

Tephra hazard zone . . . . . . . . . . . . . . . . . . . . . . . . . . . . 12

Lateral-blast zone . . . . . . . . . . . . . . . . . . . . . . . . . . . . . 12

Volcanic monitoring and eruption response . . . . . . . . . . . . . . . . . . . . 13

Summary . . . . . . . . . . . . . . . . . . . . . . . . . . . . . . 15

Glossary . . . . . . . . . . . . . . . . . . . . . . . . . . . 15

References and additional reading . . . . . . . . . . . . . . . . . . . . . . . . 16

\section{ILLUSTRATIONS}

Plate 1. Flowage hazard zones . . . . . . . . . . . . . . . . . In pocket

Figure 1. Schematic drawing of an erupting volcano showing the eruption column, tephra plume, tephra fall, tephra deposit, and ballistic debris . . . . . . . . 6

2. Average frequency of winds between the altitudes of 3,000-16,000 m (about 10,000-50,000 feet) in northwestern Washington . . . . . . . . . 6

3. Relation between distance from volcano and the thickness of tephra preserved . 7

4. Hypothetical tephra distribution and thickness from a future eruption of Mount Baker similar in size to the largest tephra producing event there . . . . . . 8

5A. Annual probability of $1 \mathrm{~cm}$ (about 0.4 inches) or more of tephra accumulation from Mount Baker . . . . . . . . . . . . . . . . . . . . . . . . 12

5B. Annual probability of $1 \mathrm{~cm}$ (about 0.4 inches) or more of tephra accumulation from any major Cascade volcano . . . . . . . . . . . . . . . . . . 13

6. Lateral blast hazard zone . . . . . . . . . . . . . . . . . . . . . 14

\section{TABLES}

1. Summary of last 14,000 years of activity at Mount Baker $\quad$. . . . . . . . . . . . . 4

Cover photo: Summit of Mount Baker from west. Photo \# 83R 1 067, September 30, 1983. U.S. Geological Survey, Ice and Climate Project, University of Puget Sound, Tacoma, WA 98416 


\title{
Potential Volcanic Hazards from Future Activity of Mount Baker, Washington
}

\author{
by
}

\author{
Cynthia A. Gardner, Kevin M. Scott, C. Dan Miller, Bobbie Myers, Wes Hildreth, and Patrick T. Pringle
}

\section{INTRODUCTION}

Mount Baker is an active volcano. Its most recent activity was in the mid-1800's at a time when permanent populations around its base were few and infrastructures, such as roads, powerlines and other structures, were virtually non-existent. Although most of the area adjacent to Mount Baker is still largely unpopulated (much of the mountain is in the Mt. Baker-Snoqualmie National Forest), population patterns and infrastructure are much different than 150 years ago, and each year greater and greater numbers of people live and play in areas that could be affected by future volcanic activity. This report discusses the types of volcanic events that are likely to affect the region.

The primary purpose of this report is to provide planners, emergency management personnel, and federal and state agencies with information regarding eruptive and other hazardous geologic processes that will likely occur at Mount Baker in the future. Hopefully it will also be of interest to the general public. A hazard-zonation map accompanies this report and designates areas that will most likely be affected by such processes. Much of the geologic rationale for the hazard designations is from work by Hyde and Crandell (1978) and from ongoing hydrologic and geologic investigations by K. M. Scott and W. Hildreth.

Throughout this report a distinction is made between magmatic and nonmagmatic volcanic activity. Magmatic activity involves magma (molten rock and associated gases) reaching the surface whereas nonmagmatic activity does not. The reason for this distinction is that the movement of magma can usually be detected through volcano monitoring; therefore, there is generally some warning prior to a magmatic event. In the case of nonmagmatic events, such as the generation of debris flows, there is generally no movement of magma and an event may not be detected until it occurs. Thus volcanic activity not directly related to an eruption also poses a serious threat.

\section{GEOLOGIC AND GEOGRAPHIC SETTING}

Mount Baker (3285 m; $10778 \mathrm{ft}$.) is an ice-clad volcano in the North Cascades of Washington State about $50 \mathrm{~km}(31 \mathrm{mi})$ due east of the city of Bellingham. After Mount Rainier, it is the most heavily glaciated of the Cascade volcanoes: the volume of snow and ice on Mount Baker (about 1.8 $\mathrm{km}^{3} ; 0.43 \mathrm{mi}^{3}$ ) is greater than that of all the other Cascades volcanoes (except Rainier) combined. Isolated ridges of lava and hydrothermally altered rock, especially in the area of Sherman Crater, are exposed between glaciers on the upper flanks of the volcano: the lower flanks are steep and heavily vegetated. The volcano rests on a foundation of non-volcanic rocks in a region that is largely non-volcanic in origin.

The present-day cone is relatively young, perhaps less than 30,000 years old, but it sits atop a similar older volcanic cone called Black Buttes volcano which was active between 500,000 and 300,000 years ago. Much of Mount Baker's earlier geologic record was eroded away during the last ice age (which culminated 15,000-20,000 years ago), by thick ice sheets that filled the valleys and covered much of the region. In the last 14,000 years, the area around the mountain has been largely ice free, but the mountain itself remains heavily mantled with snow and ice.

Deposits which record the last 14,000 years at Mount Baker indicate that Mount Baker has not had highly explosive eruptions like those of Mount St. Helens or Glacier Peak, nor has it erupted frequently. During this time period only four episodes of magmatic eruptive activity can be definitively recognized (table 1). Magmatic eruptions have produced tephra, pyroclastic flows, and lava flows from summit vents and from the 
Schriebers Meadow cinder cone. However, the most destructive and most frequent events at Mount Baker have been debris flows and debris avalanches - many, if not most, of which were not related to magmatic activity but may have been induced by steam emissions, earthquakes, heavy rainfall, or in some other way.

Historical activity at Mount Baker includes several explosions during the mid-19th century, which were witnessed from the Bellingham area, and since the late 1950s, numerous small-volume debris avalanches. In 1975, increased fumarolic activity in the Sherman Crater area caused concern that an eruption might be imminent. Additional monitoring equipment was installed and several geophysical surveys were conducted to try to detect the movement of magma. The level of Baker Lake was lowered and people were restricted from the area due to concerns that an eruption-induced debris avalanche or debris flow might enter Baker Lake and displace enough water to either cause a wave to overtop the Upper Baker Dam or cause complete failure of the dam. However, few anomalies other than the increased heat flow were recorded during the geophysical surveys nor were any other precursory activities observed to indicate that magma was moving up into the volcano. An increased level of fumarolic activity has continued at Mount Baker from 1975 to the present, but there are no other changes that suggest that magma movement is involved.

\section{VOLCANIC PHENOMENA - PRODUCTS AND THEIR ASSOCIATED HAZARDS}

\section{Phenomena That Can Occur With or Without an Eruption}

\section{Debris Flows}

Debris flows are dense slurries of water-saturated debris (rock, sand, soil, and whatever other debris is available-including trees and in extreme cases houses, cars, and bridges) that move downvalley and look and behave much like flowing concrete. They may also be referred to as lahars (indicating origin at a volcano), hyperconcentrated flows, or mudflows. Debris flows form when loose masses of unconsolidated material such as soil and rocks, glacial deposits, or pyroclastic-flow deposits are saturated with water, become unstable, and move downslope. The water can come from a variety of sources including: 1) rainfall, 2) melting of snow or ice, 3) glacial outburst floods, or 4) overtopping of crater lakes. Debris flows can also form when a large portion of a water-saturated volcanic cone collapses and moves downslope. They can be hot or cold depending upon their origin and source of their constituent debris. The speed at which debris flows move downvalley depends upon slope and sediment load. In general, they move faster on steeper slopes and, (or) with higher concentrations of debris. Average speeds are between 30 and $65 \mathrm{kph}$ (20 to $40 \mathrm{mph}$ ), although they can be as low as $10 \mathrm{kph}(6 \mathrm{mph})$ and as high as $100 \mathrm{kph}(65 \mathrm{mph})$. Debris flows follow topographic lows and are typically channeled into existing drainages, river valleys, and onto flood plains.

Debris flows can be subdivided into cohesive and noncohesive types which differ both in terms of origin and behavior. Cohesive debris flows originate as landslides of water-saturated altered rock. Many volcanoes such as Mount Baker are composed of large masses of rock that have been altered by hot fluids that can weaken the rock and break down some of the minerals into clay particles. Massive failure of these altered rocks can produce a clay-rich debris flow that travels downstream as a fairly coherent mass. Because of their clay content, cohesive debris flows do not easily incorporate stream water and therefore do not become diluted to a more watery flow or flood. Cohesive debris flows tend to sustain their movement even along fairly flat reaches until they are trapped in a lake or ocean.

Noncohesive debris flows are flows that have a low clay content. They often form during eruptions when hot volcanic material interacts with snow and ice. For example, during the 1989-90 eruption of Redoubt Volcano in Alaska, the debris flows started when hot rocks from a lava dome collapsed onto the volcano's snow-and-ice-clad flanks. The hot rocks mixed with and melted sufficient snow and ice to proceed downvalley as a debris flow. As noncohesive debris flows move downvalley they readily mix with stream water and become more and 
more diluted. In general, cohesive flows travel farther downstream as debris flows than noncohesive debris flows, which tend to transform into watery floods.

Debris flows can occur with or without an accompanying magmatic eruption. Because debris flows can be generated by various processes, both eruptive and non-eruptive, and because they can travel so far, they are the most far reaching (except for tephra fall) and common hazard associated with snow and ice-clad volcanoes.

The major hazard from debris flows to life and property is burial or impact. Because debris flows follow existing drainages, the risk tends to decrease with distance downstream and with height above the river channel; however, it is important that these factors are considered together. Thus, someone living downstream in a flat area, who may be far from the river but at an elevation not much higher, may be affected more than someone living upstream and close to the river but on a hill well above the river in height. Debris flows can erode the sides of river channels causing bank failures. Buildings, roads, water pipes, or bridge abutments built along those banks may then get incorporated into the debris flow. If large enough, debris flows can overtop river channels and carry away structures and objects in their flow paths. Debris flows can remain a major concern for many years after a large eruption has occurred. An extreme example is the 1991 eruption of Mount Pinatubo in the Philippines. There, so much loose material was deposited on the slopes of Mount Pinatubo during the eruption that during the subsequent 4 years (and likely for many more years into the future) this material has remobilized into large debris flows during periods of intense rainfall.

Debris flows have moved down all drainages that head on Mount Baker. Small debris flows (volumes of less than $0.01 \mathrm{~km}^{3} ; 0.002 \mathrm{mi}^{3}$ ) are the most frequent, but travel only a few kilometers (up to a few miles) from source; such events only pose a hazard to someone unfortunate enough to be on the flanks of the mountain and caught in the drainage when the debris flow occurs. Most such small events are probably caused by intense rainfall or small landslides that transform into debris flows and are not associated with a volcanic eruption.
Moderate-sized debris flows (volumes of $.01-0.1 \mathrm{~km}^{3} ; 0.002-0.02 \mathrm{mi}^{3}$ ) have occurred both during times of eruptive and non-eruptive activity (table 1). These flows have traveled between 10 and $14 \mathrm{~km}(6-9 \mathrm{mi})$ from the summit, thus affecting valley bottoms just beyond the flanks of the volcano. Events of this size are of special concern in drainages that head on the east and southeast sides of Mount Baker, because debris flows originating in these drainages can potentially reach Baker Lake. Depending upon the size of the debris flow and the height of Baker Lake, a debris flow entering the lake might displace enough water to cause a wave to overtop Upper Baker Dam and impact Lake Shannon and Baker Dam. Failure of Baker Dam would result in catastrophic debris flows or floods down the Skagit River. Both Upper Baker Dam and Baker Dam also have the potential of containing debris flows if lake levels are low enough and volumes of the debris flows do not exceed reservoir capacity. It has not been possible to trace debris flows down the Baker River valley because deposits are now covered by Baker Lake and Lake Shannon. Thus, it is presently unknown whether debris flows from Mount Baker have reached the Skagit River or farther downstream.

In the past 14,000 years, there has only been one event in which a debris flow exceeded a volume of $0.1 \mathrm{~km}^{3}\left(0.02 \mathrm{mi}^{3}\right)$. This event, which happened about 6800 years ago (table 1), is believed to have originated as a massive landslide on the basis of the amount of altered rock in deposits. There is no evidence of an associated volcanic eruption. This debris flow moved $12 \mathrm{~km}$ (7.5 mi) down the Sulphur Creek valley and more than $12 \mathrm{~km}(7.5 \mathrm{mi})$ down the Middle Fork of the Nooksack River. Altitudes on deposits in the Middle Fork indicate that the debris flow was at least $100 \mathrm{~m}(325 \mathrm{ft})$ deep as it moved downvalley. Deposits from this event can be traced from the Middle Fork to the main Nooksack River and as far downstream as Deming. Beyond Deming, these deposits are buried by river sediments; however, on the basis of the behavior of similarly sized cohesive debris flows at Mount Rainier and Mount St. Helens, it is likely that this debris flow continued downstream to Puget Sound. In addition to the potential devastation caused by a debris flow of this size, there is concern that deposits of future debris flows of this volume or larger, or a 
Table 1. Summary of last 14,000 years of activity at Mount Baker. Modified from Hyde and Crandell, 1978.

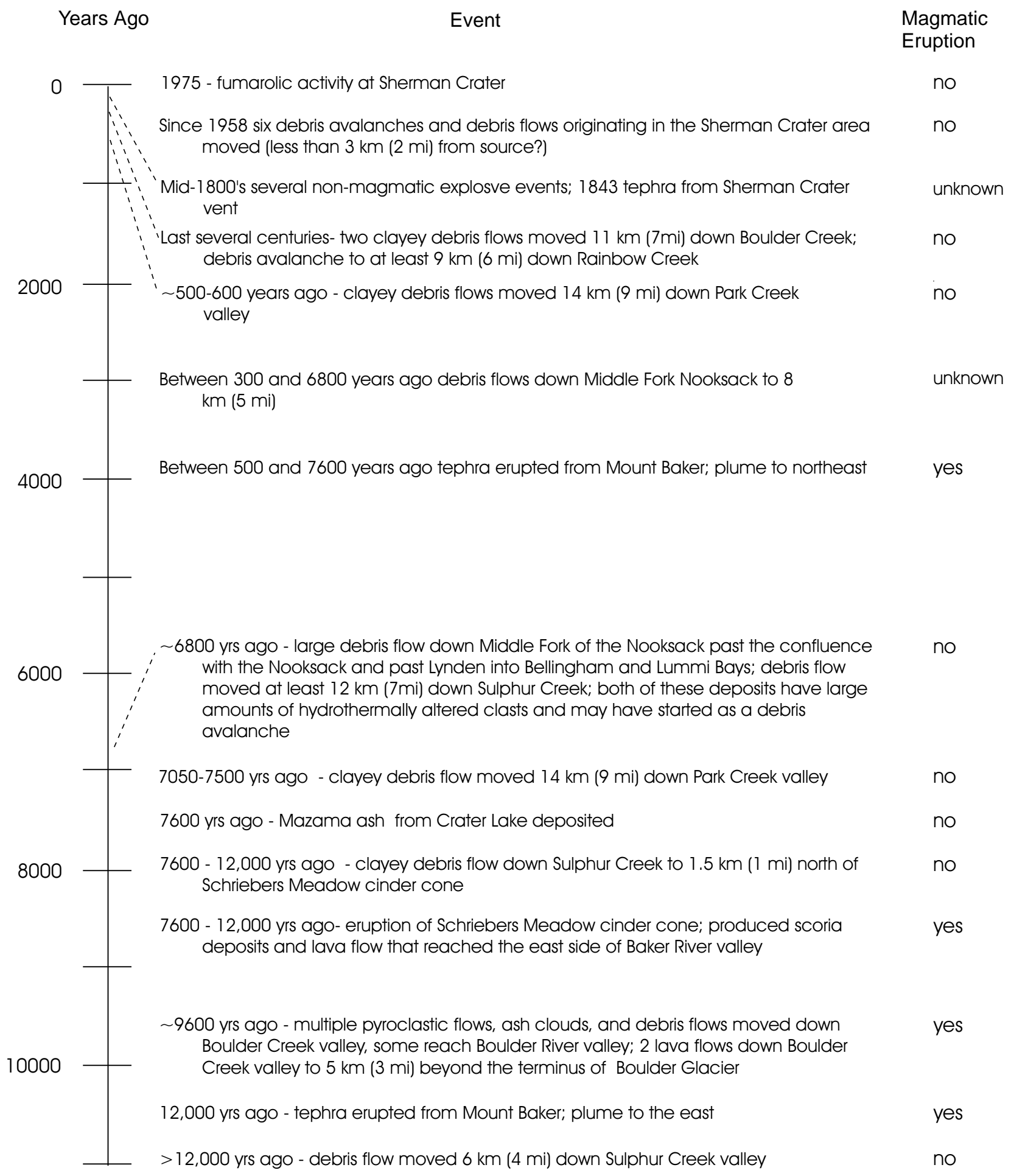

4 POTENTIAL VOLCANIC HAZARDS FROM FUTURE ACTIVITY OF MOUNT BAKER, WASHINGTON 
repeated series of large debris flows, could raise the river bed along the stretch of the river between Everson and Lynden. Such a rise in the river bed could cause the Nooksack River to overtop the divide between it and the Sumas River, resulting in flooding of the Sumas River, and, (or) diversion of the Nooksack River into the Sumas River basin.

\section{Landslides or Debris Avalanches}

Landslides are defined as the downward and outward movement of slope-forming materials natural rock, snow, glacial ice, soils or any combination of these materials: debris avalanches are a type of landslide that moves at high speeds. Like debris flows, they may or may not be accompanied by a magmatic event. Many debris avalanches will, if they contain sufficient water and fine sediment, transform downstream into cohesive debris flows.

Debris avalanches were not well recognized in the geologic record until the 1980 eruption of Mount St. Helens. Since that time, debris-avalanche deposits of varying sizes have been noted at most Cascade volcanoes and at volcanoes throughout the world. At present, it is not possible to determine just how susceptible to failure a volcanic cone is, nor is it known with confidence what has triggered debris avalanches during times of nonmagmatic activity in the past. Many debris-avalanche deposits contain a high percentage of hydrothermally altered rock, indicating that it is the combination of altered rock, steep terrain, ground water, and perhaps fractures associated with previous or concurrent magmatic intrusions that weakens volcanic cones and makes them susceptible to failure.

Like debris flows, the main hazard from debris avalanches to life and property is burial and impact. Because of their high mobility and speed, it is critical that threatened areas are evacuated before, or as soon as a large debris avalanche occurs. Because many, if not most, debris avalanches at Mount Baker transform downstream to debris flows, downvalley hazards associated with debris avalanches are those associated with debris flows.

Debris avalanches of rock, snow and glacial ice are fairly common occurrences at Mount Baker, most occurring during times of no eruptive magmatic activity. At least 6 events have taken place since 1958 , all of small volume (less than $\left.500,000 \mathrm{~m}^{3} ; 650,000 \mathrm{yd}^{3}\right)$, none of which have traveled more than $3 \mathrm{~km}$ (less than $2 \mathrm{mi}$ ) downslope. In the past century, these small debris avalanches all originated in the Sherman Crater area, an area of pervasively fractured, hydrothermally altered rock. Such minor events threaten only those unlucky enough to be hiking in the avalanche's path when the event occurs. Slightly larger sized (volumes up to $0.1 \mathrm{~km}^{3} ; 0.02 \mathrm{mi}^{3}$ ) debris avalanches have moved down Rainbow Creek valley in the last 600 years (table 1); the largest of which traveled about $9 \mathrm{~km}$ (about $6 \mathrm{mi}$ ) from its source. Deposits of this debris avalanche form a hummocky surface on the valley floor in which depressions between hummocks are occupied by small ponds and lakes, the largest of which is Rainbow Lake. These deposits and those of the last century are the only ones that researchers have expressly labeled as debris-avalanche deposits. However, many of the clay-rich debris-flow deposits, including the large Middle Fork Nooksack debris flow are interpreted to have originated as debris avalanches.

On the basis of the amount of altered rock that exists high on the volcano, the maximum credible debris avalanche from Mount Baker is estimated to have a volume of $1 \mathrm{~km}^{3}\left(0.6 \mathrm{mi}^{3}\right)$. Debris avalanches of such magnitude are recognized throughout the world at many volcanoes similar in size, composition, structure, and state of alteration as Mount Baker. No debris avalanche of this size is known to have occurred at Mount Baker during the last 14,000 years, and although one is considered possible, it is considered to have a low probability. A debris avalanche of this size would likely transform to a large debris flow that would travel to Puget Sound depending upon which side of the volcano the collapse occurred.

\section{Volcanic Phenomena That Accompany Eruptions}

\section{Tephra}

Tephra consists of fragments of molten or solid rock which are ejected into the atmosphere and then fall back to the earth's surface. The fragments are usually carried away from the volcano by the wind. 
During magmatic eruptions, a volcano blasts the fragments into the atmosphere with tremendous force, forming a vertical eruption column. Eruption columns can be enormous in size and grow rapidly, reaching tens of kilometers (miles) in height and width in 30 minutes or less. As particles in the eruption column are carried downwind they form an eruption cloud or tephra plume (figure 1). Particles in the tephra plume begin to fall out of the plume almost immediately, with the larger and heavier particles falling out close to the volcano and progressively smaller and lighter particles falling out with increasing distance downwind. Thus, the distribution of tephra is largely controlled by the strength and direction of the wind during an eruption, whereas particle size and deposit thickness are largely controlled by how explosive the eruption is and the volume of material ejected.

Tephra hazards vary from a nuisance to life-threatening. Tephra plumes pose a serious hazard to aviation because particles in plumes can damage aircraft systems and jet engines, resulting in loss of power and damage to equipment. In addition, particles in a plume can sandblast aircraft windshields such that visibility is lost. On the ground, the hazards to life from tephra vary depending upon the amount that falls and the health of individuals. In general tephra hazards diminish downwind. High concentrations of tephra can make breathing difficult for people and livestock, and thick accumulations, especially if wet, can

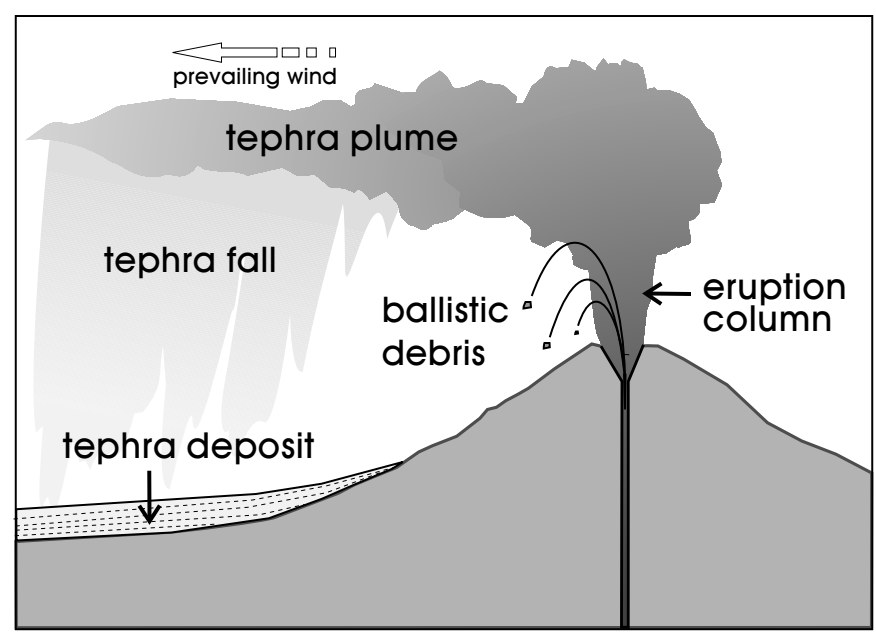

Figure 1. Schematic drawing of an erupting volcano showing the eruption column, tephra plume, tephra fall, tephra deposit, and ballistics debris. cause roofs of buildings to collapse, endangering inhabitants within. Minor amounts of tephra pose little threat to healthy individuals but may affect people with respiratory problems, the elderly, infants, and the infirm. Even minor tephra falls, however, can be detrimental to machinery (cars, lawn mowers, computers, etc.), can short out power transformers and electric lines, can be a nuisance to remove from roads and airports, can cause panic due to darkness during daylight hours, can cause traffic accidents because of reduced visibility, and can cause respiratory and eye problems for pets and livestock.

Data for wind direction and speed (fig. 2) show that winds at an altitude between $3000-16000 \mathrm{~m}$ $(10,000-50,000 \mathrm{ft})$ in the Mount Baker area are dominantly from the west with the percentage of time when winds are blowing from the north or south being fairly even. Winds blow from the east less than 10 percent of the time so that tephra from Mount Baker will normally be carried to the east away from major communities. Wind direction can be unpredictable however; wind patterns for Mount St. Helens are similar to those at Mount Baker, yet during 1980 two of the six major eruptions of Mount

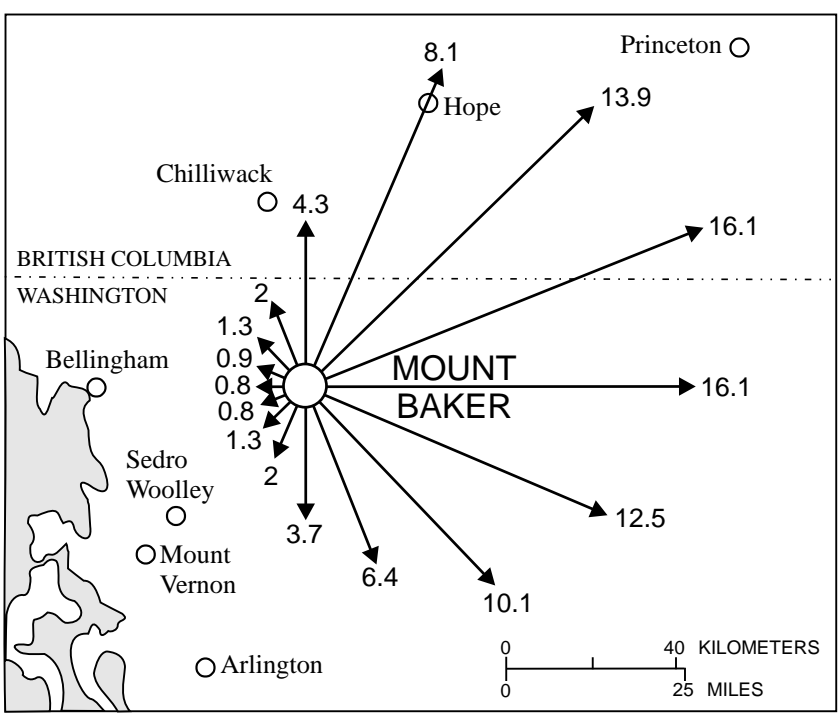

Figure 2. Average frequency of winds between the altitudes of 3,000-16,000 m (about 10,000-50,000 feet) in northwestern Washington. Winds blow towards the direction indicated and the length of the arrow (and value given at the arrow tips) reflects the percentage of the time, annually, that the wind blow in that direction. The wind diagram is centered on Mount Baker, but data are from Quillayute, Washington. 
St. Helens took place during easterly winds, resulting in tephra fallout at both Olympia and Portland. Wind speeds are generally stronger from the west than from the east, so that tephra plumes may be carried farther downwind during times of westerly winds.

Volumetrically, tephra has been a minor component of eruptions from Mount Baker, and although definitive forecasting is impossible, it seems likely that future tephra eruptions will also be relatively small in volume. Three of the four known tephra deposits from Mount Baker are related to magmatic eruptions (table 1). Two of these tephras are from vents on Mount Baker and the other one is from an eruption of the Schriebers Meadow cone. Tephra from the fourth and youngest event consists mainly of altered and older volcanic rocks and it may not be related to a magmatic eruption, but to a steam blast associated with the formation of Sherman Crater (K. Scott, work in progress, 1995).

The largest tephra event at Mount Baker is poorly constrained in age (between 550 and 7600 years ago; table 1) and has an estimated volume on the order of $0.1-0.2 \mathrm{~km}^{3}\left(0.02-0.04 \mathrm{mi}^{3}\right)$ or about one-tenth the volume of tephra from the May 18, 1980 eruption of Mount St. Helens. Other tephra events at Mount Baker have been considerably smaller. To illustrate the amount of tephra an area downwind from Mount Baker might receive, a thickness versus distance plot for different sized eruptions is shown in Figure 3. The plot shows that at distances of $50 \mathrm{~km}(31 \mathrm{mi})$, or about the distance of Bellingham from Mount Baker, thicknesses of tephra from a $0.1 \mathrm{~km}^{3}\left(0.02 \mathrm{mi}^{3}\right)$ event are on the order of $6 \mathrm{~cm}$ (about 2 in). For an event of $0.01 \mathrm{~km}^{3}$ $\left(0.002 \mathrm{mi}^{3}\right.$; ) thicknesses at $50 \mathrm{~km}$ are less than $2 \mathrm{~cm}$ (about 0.5 in). Figure 4 illustrates the possible distribution of tephra from an eruption with a volume of $0.08 \mathrm{~km}^{3}$. In this example, the data are transposed from Mount Rainier where details regarding thickness and distribution of a tephra deposit of this size are well known. During this eruption, the winds were from the west, but during a future eruption the winds could be from any direction. (The shaded area in figure 4 can be rotated around the summit to see what the thickness and distribution would be like if winds came from some other direction.) It should be noted that tephra

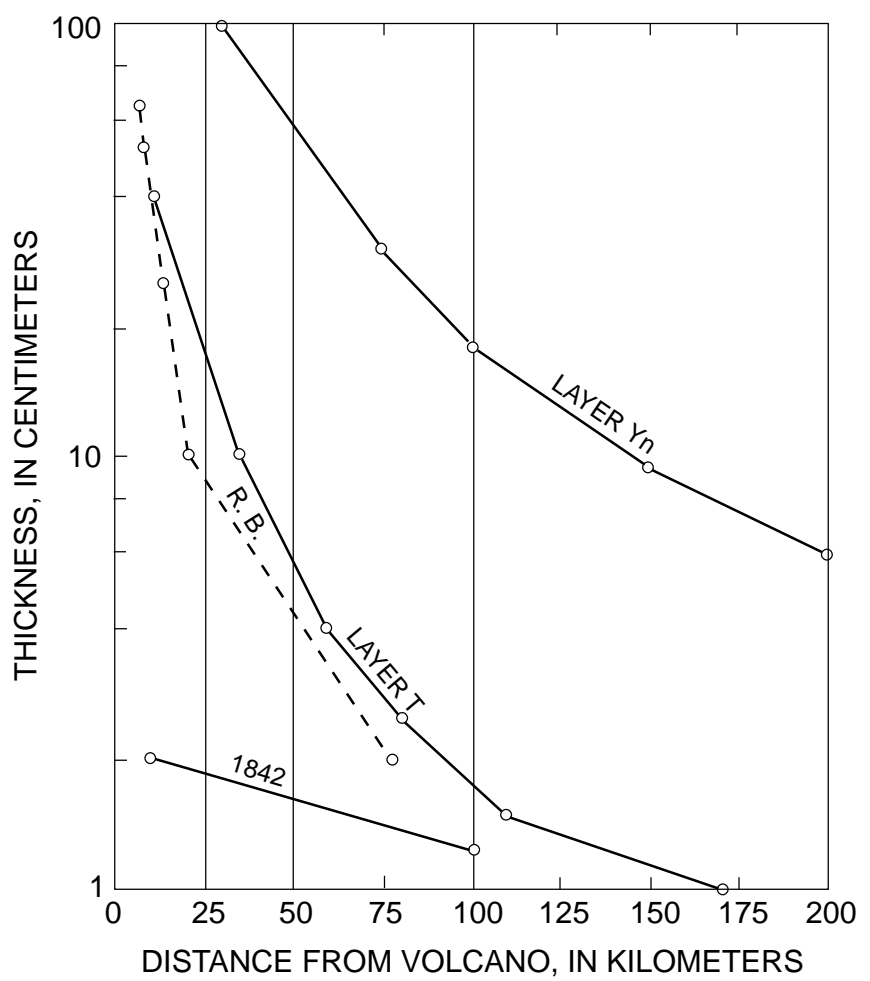

Figure 3. Relation between distance from volcano and the thickness of tephra preserved. The solid lines represent three tephra deposits of different volumes from Mount St. Helens: layer Yn, layer T, and an unnamed layer deposited in 1842. These are estimated to have volumes of approximately 1-3, 0.1 , and $0.01 \mathrm{~km}^{3}$ respectively. The dashed line represents the Reed Banks (R. B.) tephra layer from Mount Shasta, which has a volume of approximately $0.1 \mathrm{~km}^{3}$. (From Miller, 1980.)

accumulations would occur beyond the shaded area, but would be less than 1 centimeter (less than 0.4 in) in thickness.

There are two sources of tephra hazards for people living in the vicinity of Mount Baker: one is from eruptions of Mount Baker itself, the other is from eruptions of more distal and more explosive volcanoes in the Cascades. Figures $5 \mathrm{a}$ and $5 \mathrm{~b}$ shows the annual probability of an area receiving tephra from Mount Baker or from an eruption from another Cascade volcano in the United States, respectively. As can be seen from the plots, residents in the Bellingham area have a greater chance of receiving tephra from a distant volcano as from Mount Baker. Both probabilities, however, are relatively low-on the order of 1 chance in 5,000 to 1 chance in 100,000 for any given year (however, still better than the odds of winning the lottery jackpot). 


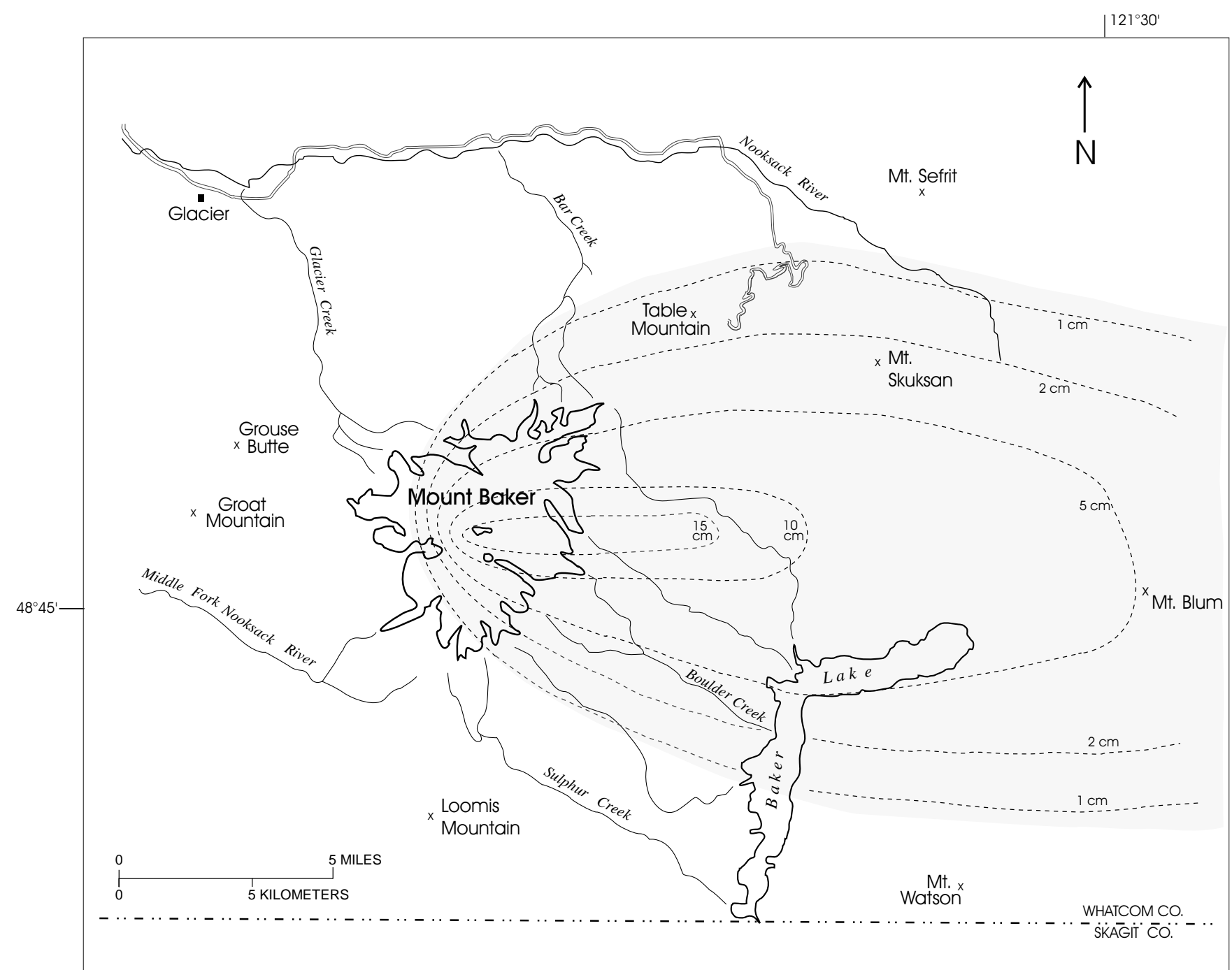

Figure 4. Hypothetical tephra distribution and thickness from a future eruption of Mount Baker similar in size to the largest tephra producing event there. The data is from an eruption of Mount Rainier with a volume of $0.08 \mathrm{~km}^{3}$ and was superimposed on Mount Baker. Orientation of a future tephra deposit will depend on prevailing winds during the eruption (see fig. 2) and may not be to the east of Mount Baker as depicted here.

\section{Ballistic Debris}

Rock fragments are often explosively blown out of a volcano either during steam explosions or magmatic eruptions. This ballistic debris moves outward from the volcano along an arc, much like a cannon ball shot out of a cannon (figure 1). The debris can range in size from pebbles to boulders. Most are thrown only a few kilometers from the vent area, although some have been thrown as far as 10 $\mathrm{km}(6 \mathrm{~m})$. The principal danger from ballistics is being hit by rock fragments (particularly large ones) moving at high speeds.

\section{Lava Flows}

Lava flows are coherent masses of hot, partially molten rock that flow downslope. They generally follow valleys, move relatively slowly, and, because they are extremely hot, burn vegetation potentially causing forest or brush fires. Lava flows that move over snow and ice can generate sufficient melt water to produce debris flows.

Most lava flows pose little risk to human life because they move so slowly and because once started, their paths can be fairly well predicted. They will destroy structures and property in their 
paths, however, by burial or burning. The secondary effects of lava flows include debris flows and forest fires that threaten life and property alike.

In the past 14,000 years, lava flows have moved down the Boulder and Sulphur Creek drainages and probably down the Glacier Creek drainage as well (W. Hildreth, work in progress, 1995). The sources for the Boulder and Glacier Creek flows appear to be high on the volcano; the source of the Sulphur Creek lava flow is the Schriebers Meadow cinder cone. The latter flow moved down Sulphur Creek valley and across the Baker River valley, temporarily damming Baker River; a remnant of the flow is found on the east side of Baker Lake. Cinder cones, like the Schriebers Meadow cone, are short-lived features and it is doubtful that new lava flows will issue from this vent. Another small volcanic cone is present $10 \mathrm{~km}(6 \mathrm{mi})$ southeast of the Schriebers Meadow cone and appears to have erupted prior to 14,000 years ago but not since. This cone is the source of a pyroclastic deposit that had earlier been interpreted as originating from Mount Baker (W. Hildreth, work in progress, 1995). The past record indicates that future lava flows will most likely have their source on Mount Baker. If a lava flow emanates from a vent high on Mount Baker, generation of secondary debris flows would be a concern, especially if the debris flows entered Baker Lake (see section on debris flows).

\section{Pyroclastic Flows, Pyroclastic Surges, and Ash Clouds}

Pyroclastic flows are avalanches of hot ash, rock fragments, and gas that move at high speeds (greater than $150 \mathrm{~km} / \mathrm{hr}$; $95 \mathrm{mi} / \mathrm{hr}$ ) down the sides of a volcano during explosive eruptions or when the edge of a thick, viscous, lava flow or dome breaks apart and collapses. Such flows can be as hot as $800^{\circ} \mathrm{C}\left(\sim 1500^{\circ} \mathrm{F}\right)$ and are capable of burning and destroying everything in their paths. Pyroclastic flows, like debris flows and lava flows, tend to follow valley bottoms or other topographic lows, but can have enough mobility to overtop hills and ridges. Often associated with pyroclastic flows are pyroclastic surges, which are more energetic than pyroclastic flows, and thus are less restricted by topography. They often move over ridge tops and slopes adjacent to pyroclastic flows. The finest particles of moving pyroclastic flows and surges are transported upward by hot gases and carried downwind as ash clouds, eventually falling out over the landscape like tephra derived directly from the vent.

Pyroclastic flows and surges are extremely dangerous and the hazards associated with them are numerous. Injury or death can result from a number of factors including burial, impact, burning, and asphyxiation. Although pyroclastic flows move down valleys like lava and debris flows, the immediate hazards associated with them are very different. In the case of lava flows, one can usually out run the advancing front. In the case of debris flows, one can climb quickly up the valley sides to a height above the debris flow. In the case of pyroclastic flows and surges, however, the high mobility and heat associated with these flows threatens anyone nearby, such that ridge tops and valley slopes may be unsafe. During a magmatic eruption at the summit of Mount Baker any of the drainages that begin high on the volcano could be affected by this phenomena.

When hot pyroclastic debris interacts with snow and ice, debris flows are generated. Owing to the large amount of snow and ice on Mount Baker, any pyroclastic flow or surge generated on the upper slopes of the volcano will produce noncohesive debris flows. Large pyroclastic-flow-induced debris flows would move into the Baker-Skagit or Nooksack River systems and travel downstream either as debris flows or watery floods.

Only one period of pyroclastic-flow and -surge activity is recognized at Mount Baker. This activity occurred about 9600 years ago and deposits from this period are confined to the Boulder Creek valley (table 1). At least 11 pyroclastic-flow and ash-cloud deposits are present there along with at least 16 debris-flow deposits and two lava flows. These deposits make up part of a large fan that forms the west bank of Baker Lake.

\section{Lateral Blasts}

Lateral blasts are explosive events in which energy is directed horizontally instead of vertically as in an eruption column. Lateral blasts vary in size, but large ones are fairly rare, with only a few historical examples known worldwide-the most 
recent occurred during the 1980 eruption of Mount St. Helens. There, the gas-charged, hot (initial temperatures greater than $300^{\circ} \mathrm{C}$ or $570^{\circ} \mathrm{F}$ ), mixture of rock, gas, and ash moved out at speeds up to 1000 $\mathrm{kph}(\sim 650 \mathrm{mph})$, and surmounted ridges as high as $750 \mathrm{~m}(2500 \mathrm{ft})$ above valley floors Within a few minutes the blast extended outwards about $25 \mathrm{~km}$ (15 mi) and had carried off or knocked down virtually all the trees in its path. Almost everything within the blast zone perished and all manmade objects were moved or significantly damaged.

No lateral blast of this magnitude has been recognized at Mount Baker, but such blasts were not recognized before 1980 at Mount St. Helens either. Such an event is considered credible, although unlikely. Because lateral blasts are directed outwards instead of upwards (one can think of them in a simple way as an eruption column lying on its side) only a portion of the area surrounding a volcano is affected by a lateral blast. At Mount St. Helens, a 180-degree sector out to a distance of 25 $\mathrm{km}$ (15 mi) from the summit was devastated buy the 1980 lateral blast. In that case, nearly two months of deformation of the north side of the volcano preceded the events that triggered the lateral blast. Similar deformation at Mount Baker would help define what areas around the volcano might be affected by a blast before one occurred.

\section{HAZARDS-ZONATION MAP}

Assessment of volcano hazards at Mount Baker is based on the philosophy that future volcanic activity is most likely to be similar to what has happened in the past. The time period since settlers have come to the area is too brief to serve as the basis for estimating the future behavior of the volcano which is hundreds of thousands of years old. Fortunately, at least some of the record of prehistoric eruptions and events is preserved in the deposits they produced. Such deposits can be mapped, studied, and dated in order to learn about the types and frequencies of past events thus to identify areas that could be affected by future events. At Mount Baker, many of the deposits older than 14,000 years were eroded away by ice sheets and so the past 14,000 years is assumed to be representative of the type of activity that has occurred throughout the volcano's lifetime.
Areas designated as hazardous are delineated on the basis of past eruptive events as well as topography, degree of alteration of the volcano (to help determine the likelihood of a debris avalanche), and knowledge of comparable eruptive phenomena at other volcanoes. Hazards are depicted in all drainages that begin high on Mount Baker - whether or not deposits of past events are preserved there. Thus, unless protected by topographic barriers, any valley starting high on Mount Baker could be affected during the next eruption.

The accompanying hazard maps shows areas that could be affected by future flowage hazards such as debris flows, debris avalanches, lava flows, pyroclastic flows, and pyroclastic surges. Tephra hazards are shown in Figure 5 ( $a$ and $b$ ) and a lateral blast hazard map is shown in Figure 6. It is important to recognize that the degree of hazard does not change abruptly at the hazard-zone boundaries. Rather, the level of hazard typically decreases gradually as one moves away from the source area, or in the case of debris flows, as one moves above the valley floor. Areas immediately outside hazard-zone boundaries should not be regarded as hazard free, because many of the boundaries can only be approximately located, especially in areas of low relief. Too many uncertainties exist about the size, mobility, and source of future events to definitively locate hazard-zone boundaries.

\section{Debris-Flow And Debris-Avalanche Zone}

The major hazard at Mount Baker is from debris flows and debris avalanches, many of which will occur without accompanying magmatic activity. The boundaries on the hazard map illustrate probable debris-flow inundation levels based largely on past extents of these events at Mount Baker. Three zones, termed Cases M, 1, and 2, are delineated in order of increasing frequency and decreasing size. The boundaries for these zones are largely the work of K. M. Scott in conjunction with data reported in Hyde and Crandell (1978).

Case $M$ represents a maximum known or envisioned debris flow for the Nooksack and Skagit Rivers. The maximum known debris flow is the 
6800 year-old debris flow in the Middle Fork of the Nooksack River that can be traced as far downstream as Deming. Flow limits are not shown below Deming, but are likely to be several meters higher than those of the Case I flows shown on the map. The likely cause of a Case $\mathrm{M}$ debris flow would be a debris avalanche that transformed into a cohesive debris flow. As only one event of this size is known, the recurrence interval is on the order of 1 in 14,000 years and so this event is considered to be a high consequence, but low-probability event.

In the Skagit River Valley, a Case $M$ flow is shown as the consequence of the failure of Baker Dam, and (or) Upper Baker Dam that sends a debris flow or watery flood down the Skagit River. A large debris avalanche, pyroclastic flow, or debris flow entering Baker Lake could cause failure of the dams. With all the potential scenarios and modes of dam failure, the possibilities are so complex that no specific downstream inundation level can be forecast. We concur with Hyde and Crandell (1978) that the only reasonable approach to a Case M event down the Skagit River is to include the entire flood plain downstream to Puget Sound. A possible inundation depth in this zone is at least 5 meters (16 feet).

A case M event is also shown for the Sumas River drainage in the case where aggradation causes the Nooksack River to overtop its divide and flow into the Sumas River.

A Case 1 event is a noncohesive debris flow related to melting of snow and ice as a consequence of magmatic eruptive activity or by increased fumarolic heating or steam explosions. The size of the flow would depend upon how much snow and ice were melted, and where on the volcano the activity occurred. This is the most likely type of event to affect the drainages on the northern side of the volcano. The recurrence interval based on known deposits of noncohesive debris flows is in excess of 500 years. However, the likelihood of a Case 1 event would be greater if precursory activity indicative of a magmatic eruption or if further increased fumarolic activity were to occur.

Case 2 events are cohesive debris flows derived from small to moderate debris avalanches of water-saturated altered rock from either the Sherman Crater or the upper Avalanche Gorge (Rainbow Creek) areas. On the east side of the volcano where Case 2 flows are designated, Case 1 flows are not likely to be significantly larger in these drainages, and consequently are not separately shown. The recurrence interval between Case 2 events is 100 years or less, representing a debris flow analogous to that of a 100-year flood. Inundation lines on the map are based on the largest such flows that have taken place since the mid-1800's. Case 2 events may occur during times of no volcanic activity or during times of increased fumarolic or other precursory activity. For both Case 1 and 2 types of events, when increased thermal activity or other types of volcanic unrest occur, it would be prudent to lower the reservoirs to accommodate moderate-sized debris flows that might enter the lake, as was done during the start of the increased fumarolic activity in the mid 1970's.

\section{Pyroclastic Flow, Surge, Lava Flow, and Ballistic Zone}

The boundary for this zone is based on the possible distribution of products during a summit eruption of Mount Baker. Because pyroclastic flows and surges tend to be the most mobile of these phenomena, the hazard zone is based on the distances that these flows are likely to travel. This is estimated by determining the difference in elevation of the eruptive vent (in this case we used the summit) and the farthest point that any flow or surge reached $(\mathrm{H})$, divided by the distance between these between these points (L), and is expressed by the simple ratio of $\mathrm{H} / \mathrm{L}$. We determined a value of $\mathrm{H} / \mathrm{L}$ (for this case of 0.2 ) based on the distance that pyroclastic flows have traveled down the Boulder Creek drainage and on our calculations for other pyroclastic flows and surges at other similar volcanoes. The resulting zone is irregular in shape because of the irregular topography around Mount Baker, which influences the flow paths of pyroclastic flows and surges.

Lava flows tend to follow topographic lows and depending upon where the next active vent is, may travel down drainages that are already designated as debris-flow hazard zones. Regardless of vent placement however, lava flows and ballistic debris are generally confined to within $10 \mathrm{~km}(6 \mathrm{mi})$ of their source; thus, during future events at Mount 
Baker the hazard zone for these two phenomena will be contained within the zone calculated for pyroclastic flows and surges. Most debris avalanches will also occur within this zone. During any given eruptive event, some drainages may be completely unaffected by pyroclastic flows, surges, or lava flows, whereas others may be adversely affected. Because of the $\mathrm{H} / \mathrm{L}$ value chosen, the area on the west-northwest side of the volcano downslope of the Black Buttes was included in the hazard zone, although the Black Buttes will provide a topographic barrier to all but the most extreme flowage events. The areas of greatest concern from the above hazards, where there are no topographic barriers to impede flows of any kind, are those areas that head above Baker Lake on the east, the Middle Fork of the Nooksack River on the southwest, and Glacier and Bar Creeks on the north.

\section{Tephra Hazard Zone}

Tephra hazard maps, shown in figures $5 \mathrm{a}$ and $5 \mathrm{~b}$, show the annual probabilities of a tephra fall of $1 \mathrm{~cm}$ (about $0.4 \mathrm{in}$ ) or more from an eruption at Mount Baker or another Cascade volcano. The data base for figure 5a (an eruption from Mount Baker) includes all tephra falls from Mount Baker in the last 10,000 years and assumes present day wind directions. The data base for figure $5 \mathrm{~b}$ includes tephra falls for all U. S. Cascade volcanoes during the last 10,000 years, and again assumes present day wind directions. The patterns for both figures are keyed to scales shown at the right of each map. A $0.002 \%$ probability means that there is 1 chance in $50,000(1 / 50,000 \times 100)$ that the area shaded with that pattern will experience an accumulation of $1 \mathrm{~cm}$ (about 0.4 in) or more of tephra during any given year.

\section{Lateral-Blast Zone}

No lateral blast deposits have been recognized at Mount Baker and a future large event is considered to have a low probability. However, in order to have a sense of the area at risk from a lateral blast comparable to the 1980 blast at Mount St. Helens, a "maximum" lateral-blast zone is shown in figure 6. The blast-hazard zone was estimated using a similar calculation as that used to determine the hazard zone for pyroclastic flows and surges, but in this case the $\mathrm{H} / \mathrm{L}$ value chosen is 0.09 . This value is based on the distance traveled by the 1980 Mount

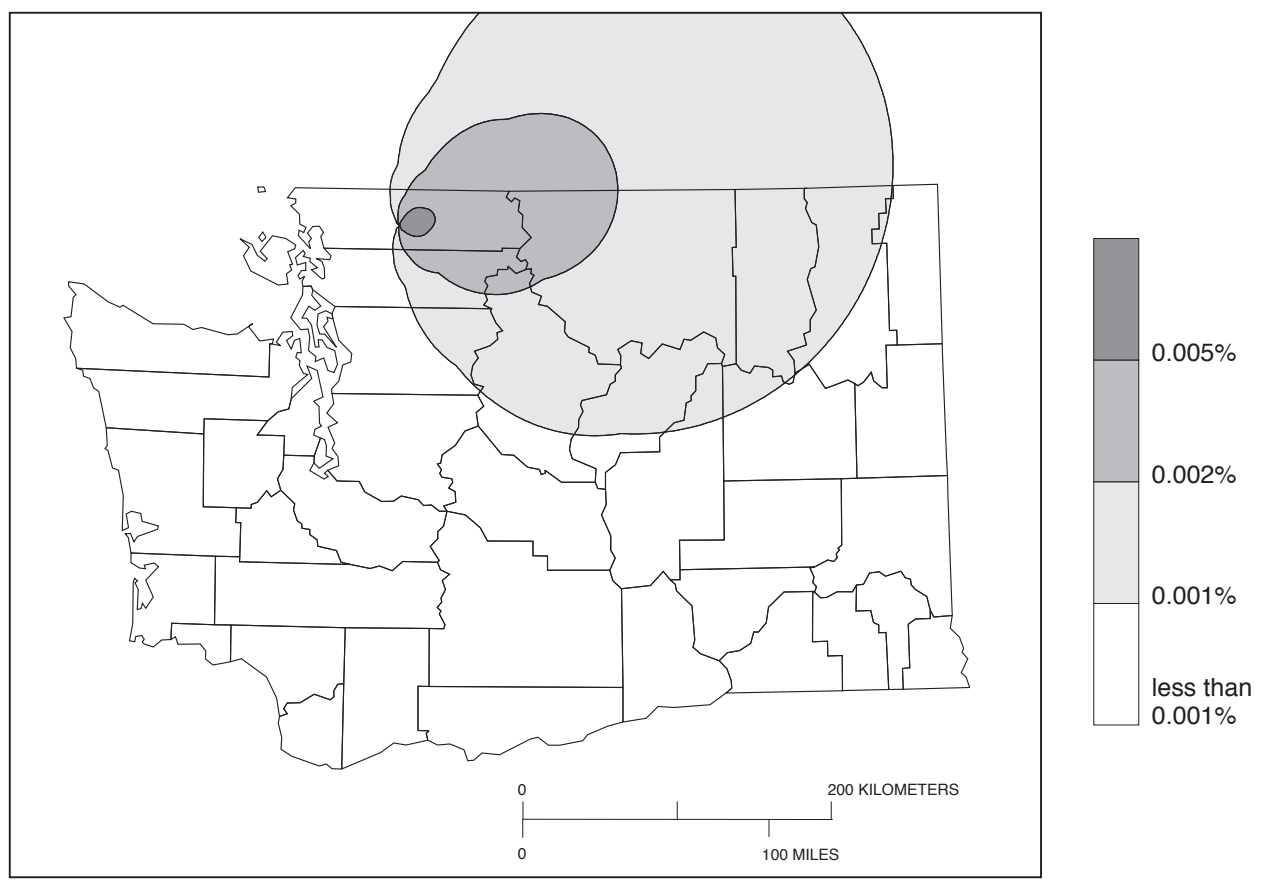

Figure 5a. Annual probability of $1 \mathrm{~cm}$ (about 0.4 inches) or more of tephra accumulation from Mount Baker. The shaded annual percentages are keyed to the scale bar at right. For example $0.005 \%$ equals a chance of 1 in 20,000 years. 


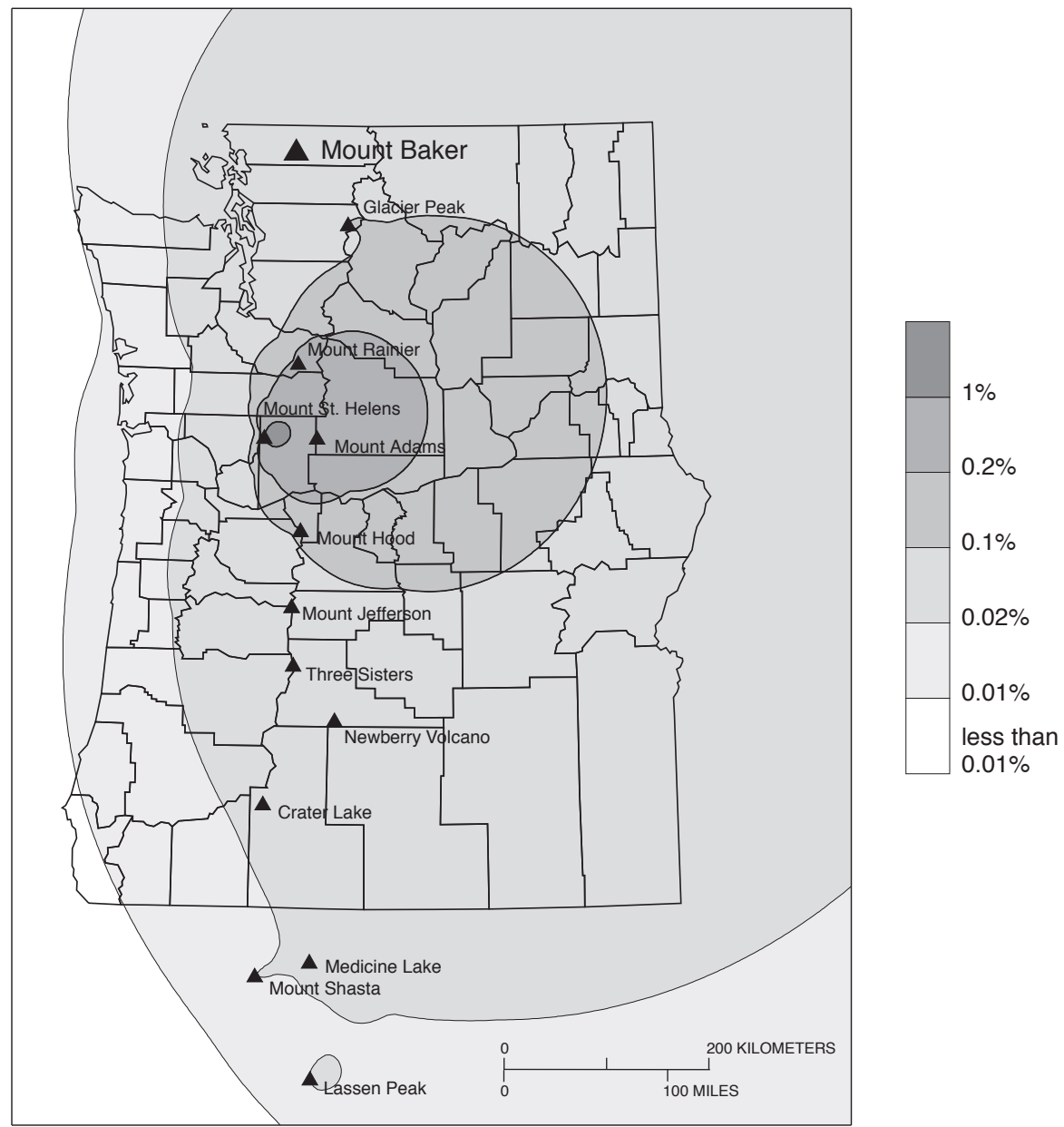

Figure 5b. Annual probability of $1 \mathrm{~cm}$ (about 0.4 inches) or more of tephra accumulation from any major Cascade volcano. Distribution is strongly affected by Mount St. Helens, the greatest tephra producer in the Cascades.

St. Helens blast. The zone is irregular because of topographic barriers, such as Mount Shuksan, which would stop the blast well short of its potential runout distance.

\section{VOLCANIC MONITORING AND ERUPTION RESPONSE}

Future magmatic eruptions at Mount Baker are likely to be preceded by changes at the volcano that can be detected by modern volcano-monitoring techniques. Magma moving up into a volcanic edifice causes rock fracturing, deforms the ground surface, and releases magmatic gases. Therefore, volcanic seismicity (earthquakes), deformation, and gas studies are the principal monitoring tools that the U. S. Geological Survey (USGS) employs to detect magma movement. In conjunction with the University of Washington's Geophysics Program, the USGS operates and continuously receives data from a network of seismometers on and around Mount Baker. Deformation measurements, that could detect magma movement within the volcano, is done to provide baseline information on the state of Mount Baker. Gas measurements and fumarole temperatures have been measured sporadically at Mount Baker since the early 1970's to detect changes in gas composition or increases in temperature, both of which may accompany movement of magma to shallow levels.

If one or more of these techniques were to show consistently anomalous behavior indicative of magma movement, additional seismic, deformation, and gas monitoring would be initiated. If the evidence indicated that conditions were developing that might lead to an eruption, USGS crews would begin monitoring the volcano on a round-the-clock basis and the status of the volcano 


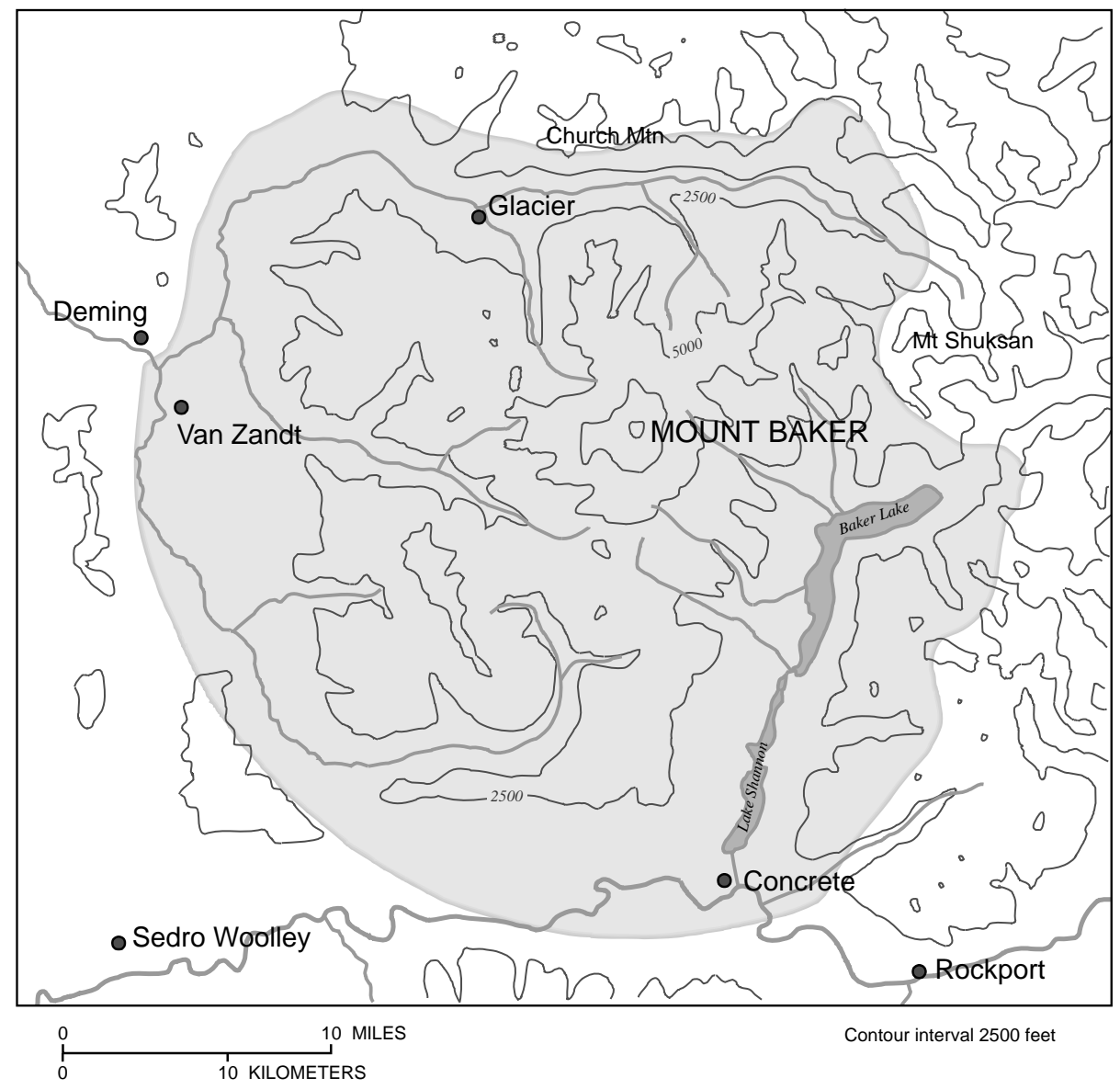

Figure 6. Lateral Blast Hazard Zone. Area that could be affected by a lateral blast similar in size to the May 18, 1980 lateral blast event at Mount St. Helens. During any given lateral blast the entire area around the volcano (360 degrees) would not be affected, but rather a sector most likely between 90 and 180 degrees .

would be communicated as often as necessary to appropriate officials at Federal, State, County, and local levels-usually through a coordinating agency. If an eruption appeared imminent and during an eruptive crisis, updates regarding the status of the volcano and anticipated tephra plume paths based on wind forecasts would be issued by the USGS at least daily to the above groups and to the aviation community. Hazard maps and delineation of hazard zones would be updated as new information dictates. If an eruption occurred, notification of the eruption would be sent out immediately to the coordinating agency and other concerned groups. Equally important, these groups would be notified of the cessation of an eruption as soon as practical; monitoring of the volcano and tracking of the tephra plume would continued for as long as the hazards persisted. Such full-scale monitoring and hazard communication would continue throughout any period of intense volcanic unrest until the monitoring evidence indicated that further activity was no longer a threat.

The onset of eruptive activity differs from volcano to volcano. The range in lead time from the start of anomalous (mostly seismic) behavior to an eruption for some well-monitored volcanoes was 2 months for the 1980 eruption of Mount St. Helens; 24 hours for the 1989-1990 eruption of Redoubt, Alaska; 2.5 months for the 1991 eruption of Pinatubo Volcano in the Philippines; and 10 months for the 1992 eruption of Crater Peak (Mount Spurr), Alaska. Because lead times prior to volcanic crises may be on the order of only a day to a few months, it is important that coordination among officials occur and decisions regarding the roles of the various agencies be made before a crisis begins. 


\section{SUMMARY}

* The main hazards at Mount Baker are from debris flows and debris avalanches. These may occur with or without an accompanying eruption.

* Most cohesive debris flows (Case 2 events) will be small to moderate in volume and will originate as debris avalanches of altered volcanic rock, most likely from the Sherman Crater, Avalanche Gorge, or Dorr fumarole area. Small volume debris flows will pose little risk to most people, but moderate volume debris flows could travel beyond the flanks of the volcano. The recurrence interval for these events is higher than for noncohesive debris flows (Case 1) because they need not be related to magmatic eruptions.

* If a summit magmatic eruption occurs, all drainages around the volcano will be susceptible to noncohesive debris flows (Case 1 events) that form as the result of hot volcanic material (pyroclastic flows, surges, or lava flows) melting snow and ice. These debris flows will likely transform downstream into watery debris flows or floods.

* Of special concern is a debris flow (of any type) or pyroclastic flow entering Baker Lake and displacing enough water to either overtop Upper Baker Dam or cause failure of the dam. Either scenario would have consequences for the stability of Baker Dam. If Baker Dam should fail, the resulting debris flow or flood would most likely affect the entire Skagit flood plain to Puget Sound.

* The largest debris flow in the last 14,000 years (6800 years ago) probably originated as a large debris avalanche. This flow moved down the Middle Fork of the Nooksack to the main Nooksack and can be traced as far downstream as Deming, where it is buried by younger river deposits. In all likelihood this debris flow traveled all the way to Puget Sound.

* A very large debris flow like the one that occurred 6800 years ago, or series of large debris flows moving down the Nooksack River, could deposit enough material in the stretch of river between Lynden and Everson to raise the river bed enough to cause flood waters to spill into the Sumas River or to divert the Nooksack River into the
Sumas River basin. Such an event is considered to be of high consequence but low probability.

*Pyroclastic flows, pyroclastic surges, and lava flows occur during magmatic eruptions. Pyroclastic flows and surges are particularly dangerous and areas that could be affected by them should be avoided during periods of volcanic unrest. Ballistic debris could be ejected during steam explosions or during magmatic events.

* Mount Baker has not produced large amounts of tephra in the past and probably will not in the future. Because winds are dominantly from the west, it is likely that any tephra that is produced will carried to the east away from most major communities. For most the tephra will only be a nuisance. However even minor amounts of tephra can affect the performance of aircraft, sandblast aircraft windshields, damage machinery, and disrupt everyday lives.

* Mount Baker is presently not showing signs of renewed magmatic activity, but someday in the future it will surely become restless again. Even without renewed magmatic activity, however, potentially hazardous geologic processes can occur. It is important that coordination among officials and decisions regarding the roles of the various responsible agencies are known in advance of a crisis. The time to plan for future events is now, while populations living near the volcano are sparse and infrastructures such as roads, bridges, and other facilities are of relatively low density.

\section{GLOSSARY}

Ash cloud - the fine material that is generated by a pyroclastic flow and rises above it.

Cinder cone - a small conical-shaped volcano formed by the accumulation of ejected cinders and other volcanic debris that falls back to Earth close to the vent area

Debris Avalanche - the very rapid and usually sudden sliding and flowage of an unsorted mixture of soil and weathered (altered) rock

Debris flow - a flowing mixture of water and rock debris, sometimes referred to as a lahar (originating at a volcano) or mudflow 
Deposit - Earth material that has accumulated by some natural process. For example, a flowing mixture of water and rock debris is called a debris flow, but when the flow ceases to move, a layer of fine and coarse rock is left which is called a debris-flow deposit.

Fumarole - a vent that releases volcanic gases, including water vapor (steam).

Fumarolic activity - volcanic gas emissions, that may be accompanied by a change in the temperature of the gases or fluids emitted.

Glacial till - an unsorted, unstratified mixture of fine and coarse rock debris deposited by a glacier.

Glacier outburst flood - a sudden release of melt water from a glacier or glacier-dammed lake sometimes resulting in a catastrophic flood, formed by melting of a channel or by subglacial volcanic activity.

Hummochy ground - a ground surface that has lots of small hills and swales; uneven ground.

Hydrothermal - pertains to hot water or the action of heated water, often considered heated by magma or in association with magma.

Hydrothermal alteration - alteration of rocks or minerals by the reaction of hot water (and other fluids) with pre-existing rocks. The hot water is generally heated groundwater and dissolved minerals.

Lateral blast - an explosive event in which energy is directed horizontally instead of vertically as in an eruption column

Lava - molten rock that erupts from a vent or fissure.

Lava dome - a steep-sided mound that forms when viscous lava piles up near a volcanic vent.

Magma - molten rock that contains dissolved gas and minerals. When magma reaches the surface it is called lava.

Pyroclastic flow - a hot, fast-moving and high-density mixture of fine and coarse particles and gas formed during explosive eruptions or from the collapse of a lava dome.

Pyroclastic surge - similar to a pyroclastic flow but of much lower density (higher gas to rock ratio).

Tephra - particles of either molten or rock erupted from a vent into the air above a volcano.

Vent - an opening in the Earth's surface through which volcanic materials (magma and gas) escape.

Volcanic cone or edifice - used here to describe the uppermost slopes and summit area of a volcano.

\section{REFERENCES AND ADDITIONAL READING}

\author{
Ash and Aircraft Safety Information
}

Casadevall, T. J., ed., 1994, Volcanic ash and aviation safety: Proceedings, First International Symposium: U. S. Geological Survey Bulletin 2047, 450 p.

\section{General Literature}

Brantley, Steven R., 1994, Volcanoes of the United States: U. S. Geological Survey general-interest publication, $43 \mathrm{p}$.

Harris, S. L., 1988, Fire mountains of the west: The Cascade and Mono Lake Volcanoes: Mountain Press Publishing Company, Missoula Montana, 379 p.

\section{Mount Baker}

Frank, D., Meier, M. F., and Swanson, D. A., 1977, Assessment of increased thermal activity at Mount Baker, Washington, March 1975-March 1976: U. S. Geological Survey Professional Paper 1022-A, 49 p.

Hyde, J. H. and Crandell, D. R., 1978, Post-glacial volcanic deposits at Mount Baker, Washington and potential hazards from future eruptions: Geological Survey Professional Paper 1022-C, 17 p.

\section{Other Cascade Volcanoes}

Lipman, P. W. and Mullineaux, D. R., eds., 1981, The 1980 eruptions of Mount St. Helens, Washington: U. S. Geological Survey Professional Paper 1250, p. 344-345.

Miller, C. D., 1980, Potential hazards from future eruptions in the vicinity of Mount Shasta Volcano, northern California: U. S. Geological Survey Bulletin 1503, 43 p.

Mullineaux, D. R., 1974, Pumice and other pyroclastic deposits in Mount Rainier National Park, Washington: U. S. Geological Survey Bulletin 1326, 83 p.

Scott, K. M., and Vallance, J. W., 1995, Debris flow, debris avalanche, and flood hazards at and downstream from Mount Rainier, Washington: U. S. Geological Survey Hydrologic Investigations Atlas HA-729: 1: 100,000 scale.

Waitt, R. B., and Mastin, L. G., 1995, Volcanic-Hazard Zonation for Glacier Peak Volcano, Washington: U.S. Geological Survey Open-File Report 95-499, 8 p.

\section{TO OBTAIN U. S. GEOLOGICAL SURVEY REPORTS YOU CAN WRITE OR CALL:}

\author{
U. S. Geological Survey \\ Branch of Distribution \\ P.O. Box 25286 \\ Denver, CO 80225 \\ (303) 202-4210
}

